\title{
Mass trapping of Pectinophora gossypiella (Saunders) (Lepidoptera: Gelechiidae) using light and sex-pheromone traps in cotton
}

\section{(Captura masiva de Pectinophora gossypiella (Lepidoptera: Gelechiidae) utilizando trampas ligeras de feromonas sexuales en el algodón)}

\author{
Muhammad Arshad ${ }^{1}$, Muhammad Irfan Ullah², Muhammad Wasim Abbas ${ }^{3}$, Asad Abdullah", \\ Usama Hassan ${ }^{5}$
}

\begin{abstract}
The pink bollworm, Pectinophora gossypiella (Saunders) (Lepidoptera: Gelechiidae) is an important insect pest of the cotton crop worldwide. Sex-pheromone and light traps were used to monitor the adult P. gossypiella population in Bt cotton field for the years 2017-18 at southern Punjab, Pakistan. The sampling of infested bolls was done to record the damage level of P. gossypiella. The sex-pheromone traps captured approximately 2-3 times more adults than light traps in all locations during 2017-18. For sex-pheromone traps, temperature showed negative and strong relation $\left(R^{2}=\right.$ 0.63-0.80) with trap catches. Fewer bolls (7.0-9.0\%) were infested in plots where sex-pheromone traps were installed compared to check plots (32-37\%). Therefore, the pheromone trapping proved an effective and eco-friendly tool for the monitoring and management of P. gossypiella. Our findings enable forecasting of seasonal P. gossypiella population providing additional information for the development of an integrated pest management program for this pest.
\end{abstract}

\section{Keywords}

Cultural control, Integrated pest management, Mass trapping, Pectinophora gossypiella

\section{Resumen}

La lagarta rosada, o gusano rosado del algodón, Pectinophora gossypiella (Lepidoptera: Gelechiidae) es una importante plaga de insectos del cultivo del algodón en todo el mundo. Para monitorear la población adulta de $P$. gossypiella en el campo de algodón Bt, se utilizaron trampas de luz y feromonas sexuales, durante los años 2017-18 en el sur de Punjab, Pakistán. El muestreo de cápsulas infestadas se realizó para registrar el nivel de daño de P. gossypiella. Las trampas de feromonas sexuales capturaron aproximadamente 2-3 veces más adultos que las trampas de luz en todos los lugares durante 2017-18. Para las trampas de feromonas sexuales, la temperatura mostró una fuerte relación negativa $\left(R^{2}=0,63-0,80\right)$ con las capturas de trampas. Se infestaron menos cápsulas (7.0-9.0\%) en las parcelas donde se instalaron trampas de feromonas sexuales en comparación con las parcelas de control (32-37\%). Por lo tanto, la captura de feromonas resultó ser una herramienta eficaz y ecológica para el seguimiento y manejo de P. gossypiella. Los hallazgos permiten pronosticar la población estacional de P. gossypiella proporcionando información adicional para el desarrollo de un programa de manejo integrado para esta plaga.

\section{Palabras clave}

Control cultural, Manejo integrado de plagas, Captura masiva, Pectinophora gossypiella

\footnotetext{
1 Department of Entomology, University of Sargodha, Pakistan. [makuaf@gmail.com, https://orcid.org/0000-0002-5442-0380]

2 Department of Entomology, University of Sargodha, Pakistan. [m.irfanullah@uos.edu.pk, https://orcid.org/0000-00022463-2665]

3 Pest Warning and Quality Control of Pesticides, Punjab, Pakistan. [swasim.abbasagmail.com, https://orcid.org/00000003-3455-328X]

4 Department of Entomology, University of Sargodha, Pakistan. [asadabdullah798@gmail.com, https://orcid.org/00000002-9059-1806]

5 Department of Entomology, University of Sargodha, Pakistan. [usamahassan9394@gmail.com]
} 


\section{Introducción}

Cotton, Gossypium hirsutum (L.) is one of the principal commercial crops and is cultivated on an area of 2.699 million hectares with an average of 11.94 million bales (Pakistan Economic Survey, 2017-18). The lepidopterous insect pests pose challenges to the cotton growers in achieving profitable cotton yield. Among the lepidopterans, the pink bollworm, Pectinophora gossypieIla (Saunders) (Lepidoptera: Gelechiidae) significantly affects the cotton crop and is difficult to control with insecticides (Lykouressis et al., 2005).

For the last few decades, extensive research work has been done on the development of integrated pest management program (IPM) for P. gossypiella (Naranjo and Ellsworth, 2010; Tabashnik et al., 2012). This insect has largely been exposed to transgenic cotton in cottonproducing countries; China, United States of America and India (Carrière et al., 2005; Huang et al., 2011; Wan et al., 2012; Choudhary and Gaur, 2015). Now, it has developed resistance to Bt toxin Cry1Ac and also against the combination with Bt toxin Cry2Ab (Dhurua and Gujar, 2011; Fabrick et al., 2014; Carrière et al., 2016; Mohan et al., 2016). Various control tactics like cultural practices, the release of sterile insects, mating disruption with pheromones and insecticide applications are being used for the control of $P$. gossypiella populations (Naranjo and Ellsworth, 2010; Tabashnik et al., 2010). However, the light taps have also been used to manage agricultural insect pests in many countries such as Brazil, China, and India (Jiang et al., 2008; Ma et al., 2009; Cowan and Gries, 2009).

Ecological research of the heliothine moths is the evidence of common usage of pheromone and light traps (Kant \& Kanaujia, 2008; Feng et al., 2009). Insect-trapping provides information with relevance to early warnings about crop infestation associated to ecological conditions (Del-Socorro and Gregg, 2001; Domotor et al., 2007; Jackson et al., 2008), and monitor the fluctuations of insect population at long-term basis (Adamczyk and Hubbard, 2006; Zalucki et al., 2009). Trap-catching can be helpful for the effective management of insect pests by the prediction of infestation rate and crop damage (Spear-O'Mara and Allen, 2014).

Our main objective was to evaluate the comparative effectiveness of gossyplure sexpheromone [Z7 Z11 - 16AC (50), Z7 E11 - 16AC (50) hexadecadienyl acetate with light traps in monitoring of $P$. gossypiella adults in cotton crop at the southern region of Punjab, Pakistan.

\section{Metodología}

\subsection{Experimental site}

The study was conducted in three localities; Multan (MLT) (3007'11.2"N $\left.71^{\circ} 32^{\prime} 37.7^{\prime \prime} \mathrm{E}\right)$, Shujaa-

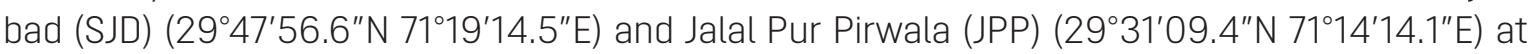
southern Punjab of Pakistan. The selected localities are about $45 \mathrm{~km}$ apart from each other. The selected regions are the main cotton producing areas in Pakistan (Figure 1).

The climate of these areas is mostly hot and dry, with a maximum of $40-44^{\circ} \mathrm{C}$ and minimum $4-10{ }^{\circ} \mathrm{C}$ temperature. The wettest month with high rainfall is July and the driest is October (Meteorological Department, Multan, Punjab, Pakistan, 2018). During 2017 and 2018, three plots were selected from each locality and the área of each plot was about 8.24 acres. Each plot was further divided into 3 blocks. One block was selected for pheromone traps only, 1 for light traps and 1 for check plot (insecticide-treated). One application of each insecticide; bifenthrin 
10\% EC, Gamma-Cyhalothrin 60\% CS and triazophos 40\% EC with 10 days interval was applied in rotation throughout the season in check plots. However, no insecticide was applied in both trapping plots. The cotton variety used in this study was Bt-2013 and sowing in all the selected regions took place between 1st to 5th May during 2017. While in 2018, sowing was done from 25 April to 1st May. In all selected plots from each location, similar practices for irrigation, cultivation, and fertilization were applied according to the recommendations of Agriculture Extension Department, Multan, Pakistan.

Figure 1. A map of Pakistan showing the selected study sites across the cotton production áreas

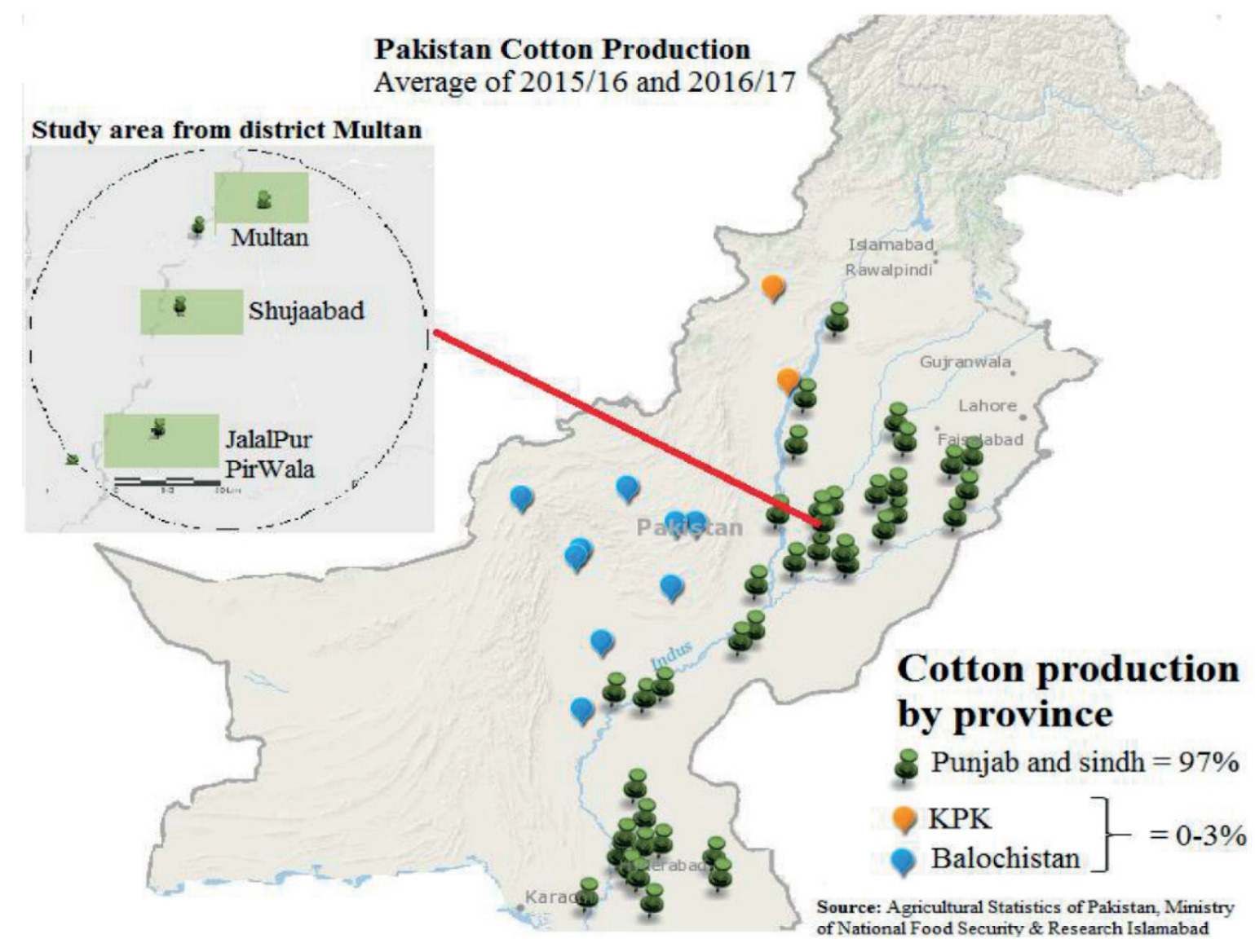

\subsection{Moth trapping}

Two sex-pheromone traps were installed at field edges (each at the opposite side) in each selected block. The delta traps were installed with the gossyplure sex-attractant pheromone [Z7 Z11 - 16AC (50), Z7 E11 - 16AC (50) hexadecadienyl acetate, (Shin-Etsu Corporation, Tokyo, Japan)]. Each trap was placed at least $60 \mathrm{~m}$ apart and rebaited every 2 weeks. The traps were placed at ca. $1 \mathrm{~m}$ height almost top level of the plant canopy. Two light traps (CSIRO-designed cone light traps) were fixed on the opposite edge of each selected block. 


\subsection{Catches - infestation}

For the infestation level of $P$. gossypiella, 300-500 bolls were sampled from each plot. The sampling was done in August and September within the first 40 rows near field edges during both seasons. Not more than one boll per plant was selected and after collection, the bolls were transferred into the laboratory and were kept at ambient temperature. Percent of boll infestation was calculated according to the formula suggested by Hajatmand et al. (2015):

$$
I=\frac{N-i}{N} \times 100
$$

$$
\begin{aligned}
& \text { Where } \\
& \text { I = infestation level } \\
& \mathrm{N}=\text { total number of bolls sampled } \\
& \mathrm{i}=\text { number of infested bolls }
\end{aligned}
$$

\subsection{Data analysis}

Data for adult $P$. gossypiella captures were analyzed using two-way ANOVA by keeping the locations and month as the main factor after checking the normality. Means were compared with tukey HSD all-pairwise comparison test. Abiotic data (temperature, humidity, and rainfall) was collected from the Metrological Department Multan, Pakistan to determine the relation with trap catches. All the data were analyzed using Minitab 17.0 statistical software.

\section{Resultados}

More adults were captured in sex-pheromone traps compared to light traps. During 2017, the range of adults captured per sex pheromone trap was 3.0-14.0 adults/trap in MLT, 0.7-13.3 adults/trap in SJD and 1.0-15.0 adults/trap in JPP location. During 2018, about 3.0-13.8 adults per sex-pheromone trap in MLT and SJD were captured followed by 3.0-12.3 adults/trap in JPP location. In the light trap, about 1.0-5.5 adults/trap was captured in all locations during both years (Figure 2).

A significant difference (2017: $F=21.4, P<0.001 ; 2018: F=8.40, P<0.001)$ of catches were found in light traps from different locations. During 2017, highest numbers of moths (0.282 adult/night/trap) were captured in light trap from MLT than other locations. In pheromone trap, highest 0.508 adults/night/trap was collected from JPP, however no significant (2017: $F=0.65$, $P>0.05 ; 2018: F=0.25, P>0.05$ ) difference was found among localities. About 0.286 moth/ night was captured in the light trap from MLT that was significantly $(P<0.001)$ higher compared to the other two locations. 
Figure 2. Average number of Pectinophora gossypiella adults captured per sex-pheromone and light trap from different locations during 2017-18
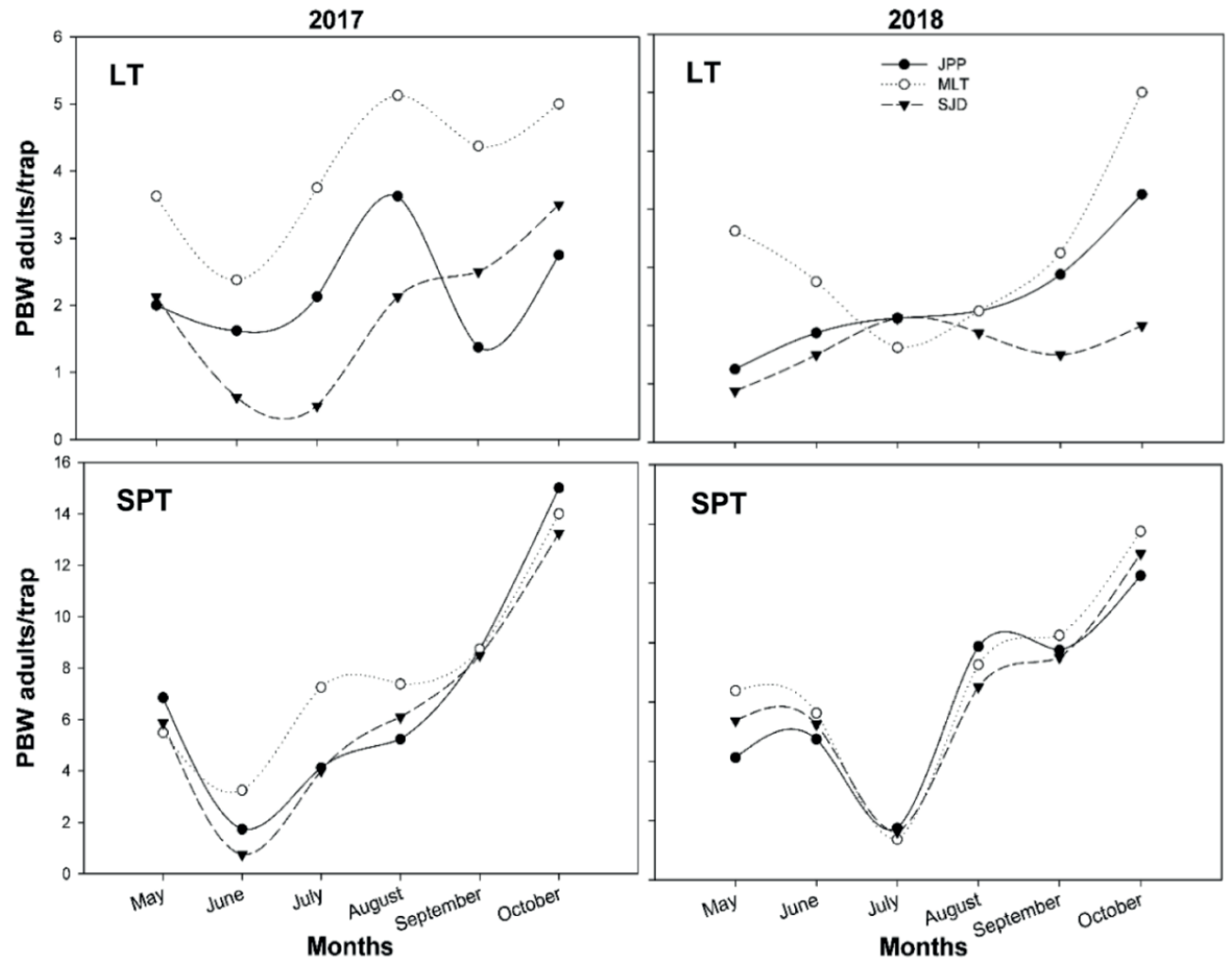

However, no significant difference $(P>0.05)$ of moth captured per night from different locations was found in case of a sex-pheromone trap. Among the locations, there was a significant difference $(P<0.001)$ in per night catches between two traps (Figure 3).

Figure 3. Average number of Pectinophora gossypiella adults captured per night per sex-pheromone and light tap from different locations during 2017-18, means sharing similar letters for light taps are not significantly different, for sex-pheromone trap, no significant $(P>0.05)$ difference was found in moth capture/night/trap
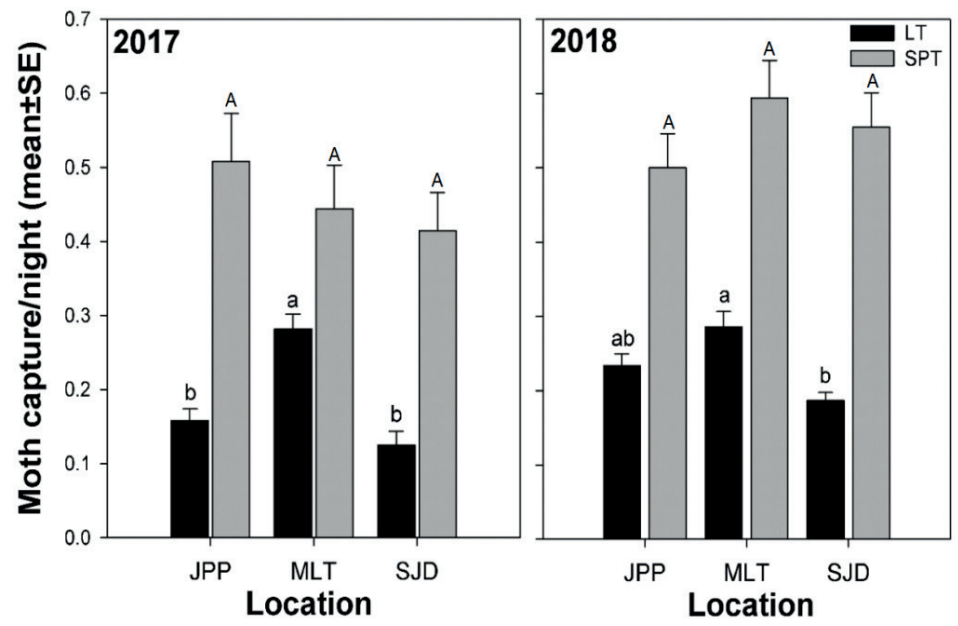
During both study years, the infestation of the boll was significantly different $(P<0.001)$ in trap-installed and check plot for each location. During 2017, no significant $(P>0.05)$ difference was found in bolls-infestation for treated and check plots across locations. However, the percent of boll-infestation was higher 32-37\% in check plots. The infestation rate was lower (7.0-9.0\%) in the plots where sex-pheromone traps were installed compared to light traps (14.0-17.5\%). During 2018, no significant ( $P>0.05$ ) difference of boll-infestation across locations was found in plots where light and sex-pheromone traps were installed. However, a significant difference $(F=$ $6.33, \mathrm{P}<0.05)$ of percent boll-infestation was found in check plots. The percent infestation was found higher (37.4\%) in check plots of MLT followed by $34.3 \%$ in SJD and $19.6 \%$ in JPP location. The rate of boll-infestation was similar in traps-installed plots as in 2017 (Figure 4).

Figure 4. Percent bolls-infestation (means \pm SE) due to Pectinophora gossypiella in trap-installed plots in comparison to check plot from different locations during 2017-18, no significant $(P>0.05)$ difference was found in bolls-infestation for all plots during 2017 and except check plot in 2018
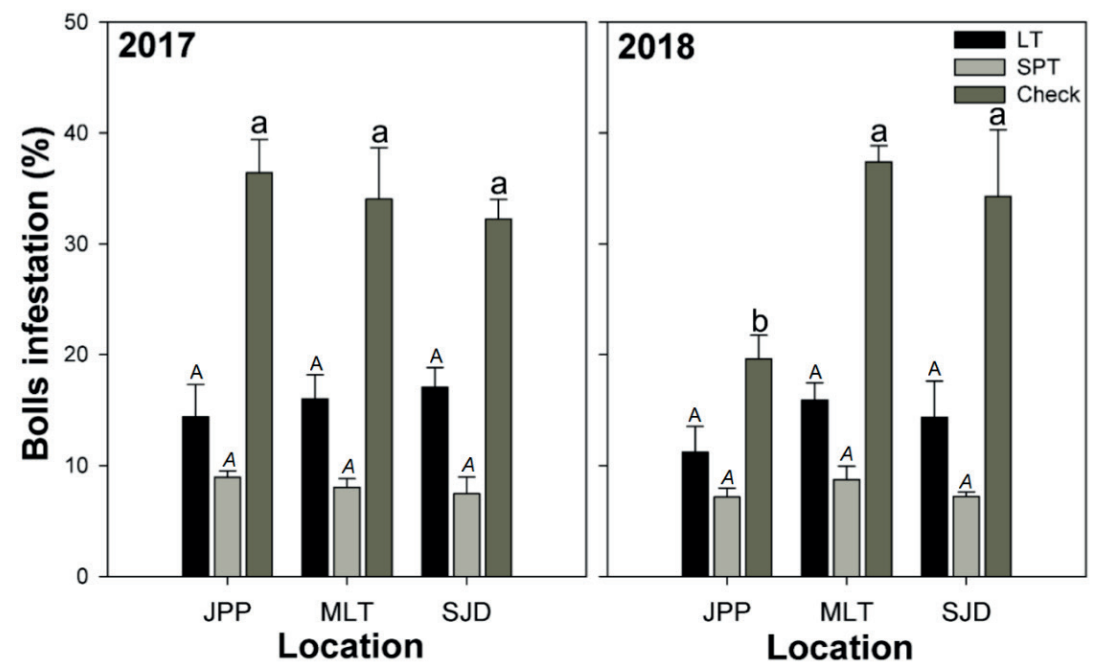

Regression analysis showed that abiotic factors had no significant effect in trap catches during both years except temperature $\left(R^{2}=0.80\right.$ for 2017 and 0.63 for 2018) that showed negative relation in case of the sex-pheromone trap (Table 1).

Table 1. Relation of abiotic factors with number of adult catches (Y) using sex-pheromone and light traps during 2017-18

\begin{tabular}{|c|c|c|c|c|c|c|c|}
\hline \multirow{2}{*}{} & \multirow{2}{*}{ Variables $(\mathbf{X})$} & \multicolumn{3}{|c|}{ Light trap } & \multicolumn{3}{c|}{ Sex-pheromone trap } \\
\cline { 3 - 8 } & & Slope (a) & Intercept (b) & $\mathbf{R}^{2}$ & Slope (a) & Intercept (b) & $\mathbf{R}^{2}$ \\
\hline \multirow{3}{*}{2017} & Temperature & -0.276 & 11.52 & 0.17 & -1.74 & 62.39 & 0.80 \\
\cline { 2 - 8 } & Humidity & 0.068 & -1.90 & 0.13 & 0.47 & -2.43 & 0.14 \\
\cline { 2 - 8 } & Rainfall & -0.113 & 0.062 & 0.17 & -0.35 & 8.53 & 0.20 \\
\hline \multirow{3}{*}{2018} & Temperature & -0.273 & 0.089 & 0.37 & -0.88 & 36.2 & 0.63 \\
\cline { 2 - 8 } & Humidity & 0.037 & 0.917 & 0.07 & 0.131 & -0.60 & 0.14 \\
\cline { 2 - 8 } & Rainfall & -0.297 & 3.717 & 0.09 & -2.05 & 10.23 & 0.72 \\
\hline
\end{tabular}

$\mathrm{R}^{2}=$ coefficient of determination, regression equation $=\mathrm{Ya}+\mathrm{bX}$ 


\section{Discusión}

The trap catching system would be useful in monitoring $P$. gossypiella populations and would help cotton growers to develop IPM strategies for the effective management of this pest (Evenden et al., 2016; Evenden, 2018). Pheromone traps were very effective in reducing the P. gossypiella with a high number of adult catches during both study years compared to a light trap. It shows the effectiveness of pheromone for male disorientation resulting in low mating success and reduction in oviposition rate in the field (Lykouressis et al., 2005). The adult capture may depend on three factors, temperature, relative humidity, and wind speed. According to Salem et al. (1990), maximum moth captured at $18.6^{\circ} \mathrm{C}$ temperature, $65-70 \%$ humidity with $6.95 \mathrm{~m} / \mathrm{s}$ wind speed. The rate of moth capturing per night was also high using sex-pheromones than the light trap in all three locations. Sex pheromone chemicals are species-specific which remains active at very low doses and are very effective in pest management in agricultural, landscape and forest areas. In contrast, the light trap is a visual attractant and attracts various insect species (Shah et al., 2011). Sex-pheromone has large attraction radius compared to light traps, therefore, more insects attract towards pheromone. In contrast to pheromone traps, the light traps are highly affected by natural factors like temperature, wind speed, rainfall and cloud cover (Yela and Holyoak, 1997). The non-target insect species especially the beneficial insects are also attracted and killed by light traps (Nabli et al., 1999), so it is a major concern as this might affect the biological control of insect pests in the field. So, pheromone traps are not harmful to the natural enemies and can be used with other control tactics such as synthetic insecticides for the effective management of $P$. gossypiella (Qureshi et al., 1985). It would likely be more effective in integrating with a recommended insecticide. So, the insecticidal application can be minimized using pheromone trapping with a specific interval. The effectiveness of mating disruption techniques with other methods has been reported earlier (Yamanaka, 2007; Suckling et al., 2014). According to Mamun et al. (2014), a combination of pheromone traps with spinosad provided maximum protection of brinjal fruits from brinjal shoot and fruit borer, Leucinodes orbonalis Guen. (Lepidoptera: Pyralidae).

It is important to note that no chemical treatments were applied in the trap-installedplots however, the bolls-infestation rate was lower in both traps as compared to check plot where insecticides were applied with a regular interval to manage the lepidopterous insect pests. The average infestation rate did not exceed $9.0 \%$ in the plots protected by pheromone trapping versus $19.0-35.0 \%$ in check plots. However, it is important to note that the data for bolls infestation was taken at the harvest time. Thus, the pheromone trapping has a significant effect in controlling the $P$. gossypiella as indicated by a smaller number of damaged bolls of cotton. Reduced mating would lead to the reduction of $P$. gossypiella larvae in the cotton field. Our results showed that temperature had a significantly negative effect on the trap catches through sexpheromone traps. Previously researchers have reported that the temperature is the important factor in the fluctuations of trap catches of many lepidopterous insects (Butler et al., 1999; Reardon et al., 2006). It might be possible that detection distance increases due to an increase in pheromone volatility with temperature (Heuskin et al., 2011).

The implementation of using pheromone and synthetic insecticides when needed could be the major components in IPM and could be helpful not only to reduce the production cost of cotton but also in increasing the yield. The insecticidal control of $P$. gossypiella is not effective unless the timing and number of applications with great precision. The harmful effect of using 
synthetic chemicals on the non-target insect pests, human health and environment is another major concern. Contrarily, mating disruption techniques are effective in controlling the P. gossypiella and have no adverse effects on the beneficial insects and environment.

\section{Conclusiones y recomendaciones}

Overall, our findings highlight the extreme variability in moth catches using sex-pheromone and light traps. It would be useful to better understand the density or abundance of $P$. gossypiella in the cotton field. Pheromone trapping is a very convenient method and is useful for the effective management of $P$. gossypiella. Further study should be conducted on trapping effeciency in different cotton cultivars with trap-cost ratio.

\section{References}

Adamczyk, J. J. J. \& Hubbard, D. (2006). Changes in Populations of Heliothis virescens (F.) (Lepidoptera: Noctuidae) and Helicoverpa zea (Boddie) (Lepidoptera: noctuidae) in the Mississippi Delta from 1986 to 2005 as Indicated by Adult Male Pheromone Traps. Journal of Cotton Science 10: 155-160.

Butler, L.; Kondo, V.; Burrows, E. M. and Towsend, E.C. (1999). Effects of Weather Conditions and Trap Types on Sampling for Richness and Abundance of Forest Macro-lepidotera. Environmental Entomology 28: 795-811.

Carrière, Y., Ellers-Kirk, C., Biggs, R. et al. (2005). Effects of Cotton Cultivar on Fitness Costs Associated with Resistance of Pink Bollworm (Lepidoptera: Gelechiidae) to Bt Cotton. Journal of Economic Entomology 98: 947-54.

Carrière, Y.; Fabrick, J. A. and Tabashnik, B. E. (2016). Advances in Managing Pest Resistance to Bt Crops: Pyramids and Seed Mixtures, (pp. 263-286). In: Horowitz, A.R., Ishaaya, I. (eds.). Advances in Insect Control and Resistance Management. Springer, New York.

Choudhary, B. and Gaur, K. (2015). Biotech Cotton in India, 2002 to 2014. ISAAA Series of Biotech Crop Profiles. ISAAA: Ithaca, NY.

Cowan, T. and Gries, G. (2009). Ultraviolet and Violet Light: Attractive Orientation Cues for the Indian Meal Moth, Plodia interpunctella. Entomologia Experimentalis et Applicata 131: 148-158.

Del Socorro, A. P. \& Gregg, P. C. (2001). Sunflower (Helianthus annuus L.) Pollen as a Marker for Studies of Local Movement in Helicoverpa armigera (Hubner) (Lepidoptera: Noctuidae). Australian Journal of Entomology 40: 257-263.

Dhurua, S. and Gujar, G. T. (2011). Field Evolved Resistance to Bt toxin Cry1Ac in the Pink Bollworm, Pectinophora gossypiella (Saunders) (Lepidoptera: Gelechiidae), from India. Pest Management Science 67: 898-903

Domotor, I.; Kiss, J. and Szocs, G. (2007). First Results on Synchrony Between Seasonal Pattern of Pheromone Trap Captures of Cotton Bollworm, Helicoverpa armigera and Appearance of Freshly Emerged Larvae on Developing Cobs of Corn Hybrids. Journal of Pest Science 80: 183-189.

Evenden, M.; Whitehouse, C.; Onge, A. S. et al. (2016). Potential for Semiochemical-based Monitoring of the Pea leaf Weevil (Coleoptera: Curculionidae) on Field Pea (Fabaceae) in the Canadian Prairie Provinces. Canadian Entomologist 148: 595-602.

Evenden, M. L. (2018). Semiochemical-based Management of the Pea Leaf Weevil (Coleoptera: Curculionidae). Annals of the Entomological Society of America 111: 154-160.

Fabrick, J. A.; Ponnuraj, J.; Singh, A. et al. (2014). Alternative Splicing and Highly Variable Cadherin Transcripts Associated with Field-Evolved Resistance of Pink Bollworm to Bt Cotton in India. PloSOne 19(5): e97900. 
Feng, H.; Wu, X.; Wu, B. and Wu, K. (2009). Seasonal Migration of Helicoverpa armigera (Lepidoptera: Noctuidae) over the Bohai Sea. Journal of Economic Entomology 102: 95-104.

Heuskin, S.; Verheggen, F.J.; Haubruge, E.; Wathelet, J. P. \& Lognay, G. (2011). The Use of Semiochemical Slow-Release Devices in Integrated Pest Management Strategies. Biotechnology, Agronomy, Society and Environment 15: 459-470.

Huang, F.; Andow, D. A. and Buschman, L. L. (2011). Success of the High-dose/refuge Resistance Management Strategy after 15 years of Bt Crop Use in North America. Entomologia Experimentalis et Applicata, 140: 1-16.

Jackson, R. E., Bradley, J.R.; Van Duyn, J. et al. (2008). Regional Assessment of Helicoverpa zea Populations on Cotton and Non-cotton Crop Hosts. Entomologia Experimentalis et Applicata 126: 89-106.

Jiang, Y. L.; Duan, Y. and Wu, Y. Q. (2008). Effects of Green-yellow Light with Three Different Wavelengths on the Oviposition Biology of Spodoptera exigua (Hübner). Acta Phytophylacica Sinica 35: 473-474.

Kant, K. \& Kanaujia, K. R. (2008). Relationship Between Moth Catches in Pheromone Trap and Larval Population Development of Helicoverpa armigera (Hub.) in Chickpea. Environment and Ecology 26: 780-782.

Lykouressis, D.; Perdikis, D.; Samartzis, D.; Fantinou, A. \& Toutouzas, S. (2005). Management of the Pink Bollworm Pectinophora gossypiella (Saunders) (Lepidoptera: Gelechiidae) by Mating Disruption in Cotton Fields. Crop Protection 24: 177-183.

Ma, C. S.; Ma, G.; Chang, X. Q. \& Yang, H. P. (2009). Environment Friendly Methods for Controlling Cotton Bollworm Moths, Helicoverpa armigera. Chinese Journal of Environmental Entomology 31: 220-226.

Mamun, M. A. A.; Islam, K. S.; Jahan, M. and Das, G. (2014). Comparative Potency of Three Insecticides Against the Infestation of Brinjal Shoot and Fruit Borer, Leucinodesorb onalis Guen. Scholars Academic Journal of Biosciences 2: 364-369.

Mohan, K. S.; Ravi, K. C.; Suresh, P. J.; Sumerford, D. and Head, G. P. (2016). Field Resistance to the Bacillus thuringiensis Protein Cry1Ac Expressed in Bollgard ® Hybrid Cotton in Pink Bollworm, Pectinophora gossypiella (Saunders), Populations in India. Pest Management Science 72: 738-746.

Nabli, H.; Bailey, W. C. \& Necibi, S. (1999). Beneficial Insect Attraction to Light Traps with Different Wavelengths. Biological Control 16: 185-188.

Naranjo, S. E. and Ellsworth, P. C. (2010). Fourteen Years of Bt Cotton Advances IPM in Arizona. Southwestern Entomologist 35: 437-445.

Pakistan Bureau of Statistics. (2018). Pakistan Economic Survey, 2017-18. Ministry of Finance, Government of Pakistan. Retrieved on 2020, from http://www.finance.gov.pk/survey/chapters_18/ Economic_Survey_2017_18.pdf

Qureshi, Z. A.; Ahmed, N. and Bughio, A. R. (1985). Efficacy of Gossyplure for the Control of Pink Bollworm, Pectinophora gossypiella (Saund.) (Lep., Gelechiidae). Zeitschrift für Angewandte Entomologie 100: 476-479.

Reardon, B. J.; Sumerford, D. V. \& Sappington, T. W. (2006). Impact of Trap Design, Windbreaks, and Weather on Captures of European Corn Borer (Lepidoptera: Crambidae) in Pheromone-baited Traps. Journal of Economic Entomology 99: 2002-2009.

Salem, S. A.; Radwan, S. M. E. \& Hamaky, M. A. (1990). Prospects of Using Sex Pheromone for the Control of Cotton Bollworms, Earias insulana Boisd. and Pectinophora gossypiella Saund, in Cotton Fields. Annals of Agricultural Sciences 28: 1743-1752.

Shah, M. A.; Memon, N. and Baloch, A. A. (2011). Use of Sex Pheromones and Light Traps for Monitoring the Population of Adult Moths of Cotton Bollworms in Hyderabad, Sindh, Pakistan. Sarhad Journal of Agriculture 27: 435-442.

Spear-O'mara, J. and Allen, D. C. (2014). Monitoring Populations of Saddled Prominent (Lepidoptera: Notodontidae) with pheromone-baited traps. Journal of Economic Entomology 100: 335-342. 
Suckling, D. M.; Stringer, L. D.; Baird, D. B. et al. (2014). Light Brown Apple Moth Epiphyas postvittana (Lepidoptera: Tortricidae) Colonization of California. Biological Invasions 16: 1851-1863.

Tabashnik, B. E.; Sisterson, M. S.; Ellsworth, P. C. et al. (2010). Suppressing Resistance to Bt Cotton with Sterile Insect Releases. Nature Biotechnology 28: 1304-1307.

Tabashnik, B. E.; Wu, K. and Wu, Y. (2012). Early Detection of Field-evolved Resistance to Bt Cotton in China: Cotton Bollworm and Pink Bollworm. Journal of Invertebrate Pathology 110: 301-306.

Wan, P.; Huang, Y.; Wu, H. et al. (2012). Increased Frequency of Pink Bollworm Resistance to Bt toxin Cry1Ac in China. PLoSOne 7: e29975.

Yamanaka, T. (2007). Mating Disruption or Mass Trapping? Numerical Simulation Analysis of a Control Strategy for Lepidopteran Pests. Population Ecology 49: 75-86.

Yela, J. L. and Holyoak, M. (1997). Effects of Moonlight and Meteorological Factors on Light and Bait Trap Catches of Noctuid Moths (Lepidoptera: Noctuidae). Environmental Entomology 26: 1283-1290.

Zalucki, M. P.; Adamson, D. \& Furlong, M. J. (2009). The Future of IPM: Whither or Wither? Australian Journal of Entomology 48: 85-96. 